\title{
Socio-economic and Bio-physical Resources Characterization of 'Warja' Watershed in Adami Tulu Jido Kombolcha District, East Shewa Zone, Oromia, Ethiopia
}

\author{
Bonsa Fentale Jilo, Gemeda Terfassa Fida, Desta Negayo Komicho \\ Oromia Agricultural Research Institute, Adami Tulu Agricultural Research Center, Agroforestry Research Team, Batu (Ziway), Ethiopia \\ Email address: \\ bonsafantale@gmail.com (B. F. Jilo), gemedaterfassa@gmail.com (G. T. Fida), negeyo.desta@gmail.com (D. N. Komicho) \\ To cite this article: \\ Bonsa Fentale Jilo, Gemeda Terfassa Fida, Desta Negayo Komicho. Socio-economic and Bio-physical Resources Characterization of 'Warja' \\ Watershed in Adami Tulu Jido Kombolcha District, East Shewa Zone, Oromia, Ethiopia. American Journal of Modern Energy. \\ Vol. 6, No. 6, 2020, pp. 101-116. doi: 10.11648/j.ajme.20200606.11
}

Received: November 13, 2020; Accepted: November 30, 2020; Published: December 11, 2020

\begin{abstract}
Watershed development is an important component of rural development and natural resource management strategies in many countries. The study was conducted to investigate the current situation of Warja watershed for further improvements to promote Sustainable and productive livelihood through the integration of different watershed components in participatory approach. Household interview and biophysical resources assessment followed by watershed mapping techniques were used for the data collection. Purposive sampling methods were used to select 63 households and Warja watershed boundary was delineated and its map was developed based on the preliminary outlet identified with the help of GPS reading. Descriptive statistics and diversity indices were used for data analysis. The results of the study indicated that Agriculture was the principal occupation $(98.4 \%$ ) of the population of Warja watershed. The average farmland size was 1.9 hectares while $25 \%$ of the households have farmland ranging from 0.25 to 1 hectare. The minimum and maximum family size of the sample farm households was 2 and 16 respectively. The common types of off-farm income generating activities are petty trade and working as daily labor. Slope gradient of Warja watershed ranges from 0 to more than 30 and the slope gradient of 2-5 and 5-10 cover the greatest in area coverage representing 204ha and 145ha respectively. Soil laboratory analysis result showed that sandy loam was the major soil type of Warja watershed. Overall results concluded that land degradation and biodiversity loss were a serious concern and watershed management programs could be strengthened. Awareness creation and strengthening capacity of rural communities on integrating crops, livestock and natural resource management technologies for effective soil and water conservation measure should be enhanced through participatory integrated watershed management approach.
\end{abstract}

Keywords: Characterization, Constraints, Mapping, Soil Properties, Species Diversity, Use Value Index

\section{Introduction}

\subsection{Background and Justifications}

In Ethiopia Watershed management programs commenced in a formal way in the 1970 s. From that time up to the late 1990s, it was a government-led, top-down, incentive based (food-for-work) approach that prioritized engineering measures that focused primarily on reducing soil erosion. Since then the government, non-governmental organizations and local community efforts on rural development have been based on watershed development program [10]. In the early 2000s, community-based integrated watershed development was introduced to promote watershed management as a means to achieve broader integrated natural resource management and livelihood improvement objectives within prevailing agroecological and socioeconomic environments [16].

According to [8] a watershed is a topographically delineated area that is drained by a stream system i.e. all of the land draining its rain, snowmelt and ground water into a stream or river. At the earlier watershed management had a narrow focus primarily for controlling erosion, floods and maintaining sustainability of useable water yield. However, recently watershed management is not only for managing or conserving natural resources in a holistic manner, but also to involve local people for betterment of their lives. Its 
management is more people oriented and process based, than only physically target oriented [2].

Factors that contribute to the success of watershed management are multidimensional, including biophysical, institutional and socioeconomic elements. The presence of supporting institutional structures and the extent of community participation were also other factors found to significantly influence the 'success' of watershed management [16]. The lack of integration from the different disciplines, sectors and limited level of participation of the stakeholders are among the limiting factors contributed to low level of success [6].

Baseline characterization helps understand the initial livelihood condition of the people in the watershed before intervention. It builds necessary foundation for the plan and obtains proper information for effective planning, implementation and monitoring [12]. Due to demographic pressure the average landholding in the Ethiopian watersheds is often fragmented and less than one ha [26]. The fragmented landholding (3-5 parcels) coupled with the improper land use system, nutrient depletion, drought and drainage problem, low crop and livestock productivity worsened the situation. Deforestation for cultivation, wood for fuel and construction, overgrazing, conversion of marginal lands to agriculture is escalating the problem of soil erosion and land degradation than ever [4].

Some impact studies have showed that investments in watershed management in the developing world do pay off in economic terms. However, such impact studies do not typically include detailed socio-economical components [13]. Similarly, Watersheds management in East Shewa including Warja watershed has got attention for more technical interventions to restore degraded lands and improve livelihood benefits. Before that a detail biophysical and Socio-economic characteristics of the watershed must be known for accurate problem solving. Several challenges that threaten the efficiencies of watershed for local community livelihood improvement exist in the in area. These include the lack of technical provision and information to support the selection of interventions suitable for the local context; uncoordinated interventions, institutions and actors within a watershed. This watershed is among the watersheds that discharge water to the big out late i.e. Dambal Lake. Managements of this and other surrounding watersheds help improve and sustain the lifespan of the lake while reduce its vulnerability to the changing climate. The managed water sources are buffer for productive ecosystem. Therefore, the analysis from biophysical and socioeconomic information in the watershed helps prioritize the problems with their appropriate management options and technologies which in turn leading to the implementation phase so that all the community in the watershed will be benefited.

\subsection{Objectives of the Study}

\subsubsection{General Objectives}

To investigate the current situation of Warja watershed for further improvements to promote Sustainable and productive livelihood through the integration of different watershed components in participatory approach.

\subsubsection{Specific Objectives}

To delineate and map the selected watershed based on existing land uses.

To characterize biophysical resources of the watershed with basic livelihood aspects of the surrounding society.

To describe and evaluate the present resource use, management practices and socio-economic conditions in the watershed

\section{Materials and Methods}

\subsection{Description of the Study Area}

\subsubsection{Geographical Location}

The study was conducted in Adami Tulu Jido-Kombolcha (ATJK) district of East Shewa of Oromia, Ethiopia, where soil degradation, gully formation and loss of agricultural land are a serious problem. Adami Tulu Jido Kombolcha (ATJK) district is located between $7.58^{\circ} \mathrm{N}$ and $38.43^{\circ} \mathrm{E}$ longitudes (Figure 1). It is bordered to the North by Dugda Bora Woreda, in the west by Southern Nations Nationalities Peoples Region (SNNPR), Arsi Negele to the south and Arsi zone to the East. Batu is the capital of the Woreda, which is $160 \mathrm{~km}$ away from Addis Ababa and $40 \mathrm{~km}$ from ASLNP [14].

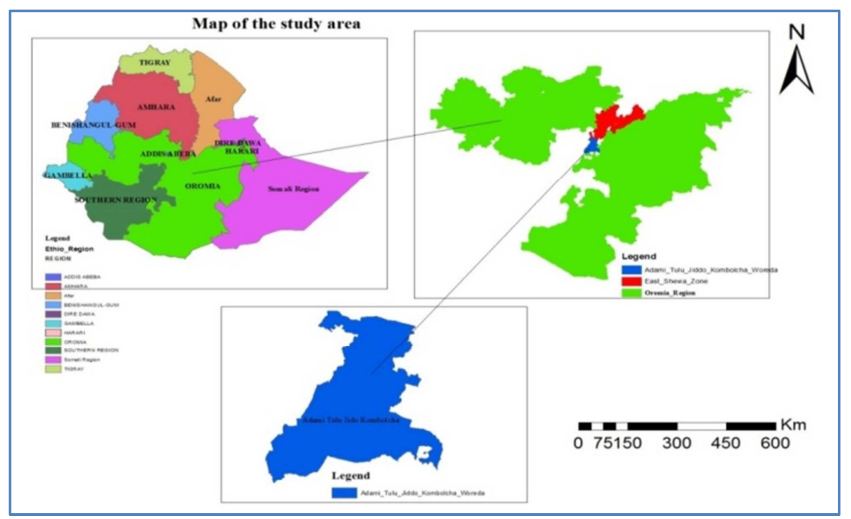

Figure 1. Location Map of Adami Tulu Jido Kombolcha District.

\subsubsection{Topography and Climate}

The area is characterized by plain and flat lands of volcanic origin with small mountains, hills and gorges extending from the most northern part of Central Rift Valley. The altitude ranges from 1500-2300 m.a.s.l. Adami Tulu Jido Kombolcha Woreda has semi-arid and arid agro-climate zones. The Woreda receives an average annual rainfall of 760 $\mathrm{mm}$. The mean monthly temperature varies from $18.5^{\circ} \mathrm{C}$ to $21.6^{\circ} \mathrm{C}$ with mean annual temperature of $20^{\circ} \mathrm{C}$. Rainfall extends from February to September with a dry period in May to June, which separates the preceding short rains from the following long rains [14].

\subsubsection{Vegetation, Soil and Land Uses}

The vegetation is characterized by scattered acacia wood land is categorized as tropical savannah Acacia trees are dominant and important means of livelihood for the local 
people [18]. The $\mathrm{pH}$ of soil is 7.88 fine sandy loams with the highest sandy proportion [9]. Most of the area is topographically flat having sandy loam and andosol soil types [11]. Three land use systems: (a) croplands under small holder subsistence farming system (b) controlled grazing lands with closed areas (i.e., the Abernosa Ranch now days partially converted to private owners big farms), and (c) communal open access grazing land exist in the study area. Soil texture at these land uses is sandy loam with greater proportion of sand fractions. $\mathrm{PH}$ of the soil in a scattered acacia farm land is less alkaline than other land uses [22].

\subsubsection{Population}

According to the Woreda agriculture and rural development office, the total population of the Woreda is estimated at 164,321 for the year 2006 Population and housing census which accounts a $3 \%$ population increase every year) of which $14.5 \%$ urban and $85.5 \%$ rural dwellers. The average household size was 4.6 with 4.9 and 4.2 for rural and urban areas, respectively. The population density was 99 persons per square kilometer. With regard to ethnic and religious composition $78.7 \%$ are Oromos, $21.3 \%$ are other ethnic groups. Muslims are $72.4 \%, 27.4 \%$ Christian and $0.2 \%$ others [15].

\subsection{Methods of Data Collection}

Before data collection started, different stakeholders, roles and responsibilities of each stakeholder were identified. The interdisciplinary team was formed from the research divisions of Adami Tulu Agricultural Research Centre for site characterization, planning and implementation of the watershed research. The following disciplines were considered for team formation: socio-economics, livestock, and geographic information system (GIS).

\subsubsection{Watershed Delineation and Mapping}

1. Sample points Design and Technique

Initially reconnaissance survey was conducted with community leaders and government administrators to identify the watershed boundary. Based on the preliminary outlet identified during the site selection process, the watershed boundary was delineated using primary data (GPS readings), secondary data (topographic map) and in consultation with the local community.

The delineated watershed was geo-referenced and digitized for its contour, roads, rivers, and other features. The preliminary delineated boundaries were verified in the field using GPS and establish reference benchmarks for future operations. Finally, map of the watershed was produced; other information such as elevation ranges, area, slopes and aspect was extracted.

After delineation, the Digital Elevation Model was derived. 18 points three each from all slopes were selected systematically. Map of the Warja watershed was developed and delineated from 1:50,000 scale topographic map and aerial photographs/satellite images. This was employ GIS tools like aerial photo interpretation using Stereoscope or satellite image interpretation using different software.

\subsubsection{Socio-economic Data Collection}

Local institutions and social and administrative boundaries were identified, described and analyzed with respect to the watershed boundaries. Then, the existing local livelihood constraints of production were identified. Important parameters for Socio economic database were collected.

Also any factors expected to influence farmers' land management practices were also examined. In addition, production constraints were analyzed and prioritized with the whole community participation. PRA tools like group discussion, trend analysis, problem ranking was employed to generate information and questionnaires were used to quantify important variables. SPSS computer software v. 20 was used for socioeconomic data analysis. Based on the data obtained, statistical tools like cross tabulation, percentages, graphs, etc were used to analyze quantitative data.

1. Household survey

$25 \%(1 / 4)$ of population of watershed $(n=63)$ was selected according to [6] stated the ideal sample should cover $20-25 \%$ of the households in the Watershed as representative of socio economic aspects. Warja watershed and households from the area were selected through purposive and random selection methods respectively. FGD (containing 6-8) members and 10 key informants were selected purposefully.

Table 1. Total population characteristics of Warja Kebele and Warja watershed society.

\begin{tabular}{lllll}
\hline Warja Kebele & & \multicolumn{3}{c}{ Warja watershed } \\
\hline Sex category & HH heads & Total & HH heads & Total \\
\hline Male & 282 & 1,550 & 196 & 621 \\
Female & 250 & 1,601 & 53 & 733 \\
Total & 532 & 3151 & 249 & 1354 \\
\hline
\end{tabular}

Source: Warja Kebele Office, 2017.

\subsubsection{Biophysical Resource Survey}

The current land use/land cover of the watershed was assessed and mapped depending upon the availability of historical data (existing maps, aerial photographs, knowledge of the local community and satellite images) and GPS respectively.

The map produced by image interpretation was crosschecked and verified by field observation. The boundary coordinates was collected using GPS. Then each land unit was characterized in terms of different parameters (quality indicators). This includes soil Physical, chemical and biological parameters, vegetation and topography.

The seasonal climate pattern of the watershed was determined using data collected from the nearest weather station. The most rainfall features include onset date, end date, duration, dry spells and rainfall amount and intensity which serve as a basis for land capability and determination of the risk of production. Similarly, the most important drought characteristics (frequency, intensity, severity and magnitude) were determined using standardized precipitation index (SPI). Temperature data was also analyzed.

1. Vegetation data collection

A $10 \mathrm{mx} 10 \mathrm{~m}$ quadrant was used to collect vegetation data 
across slopes. Quadrants were set three times at each slope randomly. Seedlings with height below $0.3 \mathrm{~m}$ were not included in the study as they were difficult to identify and are known to have very high mortality [23].

2. Soil sample collection

18 Soil samples were taken from every systematically selected point across the slope. During systematic sampling points allocation all slopes in three land uses (Crop land, protected area and grazing land) were purposively selected. Points were loaded to GPS and navigated until the destination. Then samples were collected using $20 \mathrm{~cm}$ auger to analyze important soil physical chemical properties.

3. Erosion Assessment and Detection

Availability of erosion was detected by using field observation indicators used by National Range and Pasture Handbook and Erosion (190-VI-NRPH, December 2003). Some of these factors are accounted for in the range land health and pasture condition scoring models. After the availability of the erosion detected Gullies were digitized by using GPS.

The indicators include:

Pedestalled plants and rocks

Base of plants discolored by soil movement from raindrop splash or overland flow

Exposed root crowns

Formation of miniature debris dams and terraces

Puddled spots on soil surface with fine clays forming a crust in minor depressions, which crack as the soil surface dries and the clay shrinks

Rill and gully formation

Accumulation of soil in small alluvial fans where minor changes in slope occur

Surface litter, rock, or fragments exhibit some movement and accumulation of smaller fragments behind obstacles

Eroded inter space areas between plants with un natural gravel pavements

Flow patterns contain silt and/or sand deposits and are well defined or numerous

Differential charring of wood and stumps indicating how much soil has eroded after a fire

4. Climatic data Collection

Five years secondary data were taken from Adami Tulu Agricultural Research Center weather station. ATARC weather station is one of the nearest stations to the study area. This is because in principle climate data can be taken from the nearest weather station to the study area and it is around 7 $\mathrm{km}$ from the study area.

\subsection{Methods of Data Analysis}

\subsubsection{Household Survey Data Analysis}

The qualitative data collected through questionnaire based survey were entered into Statistical Package for Social Sciences (SPSS V 20) computer program and analyzed using descriptive statistics and Frequencies.

\subsubsection{Soil Data Analysis}

The most common method of measuring soil BD is by collecting a known volume of soil using a metal ring pressed into the soil (intact core), and determining the weight after drying [21]. Other soil physical and chemical properties were analyzed using standard Laboratory procedures at Batu Soil Research Center.

The samples are then prepared for analysis following standard sampling and lab procedure. Finally prepared soil samples were analyzed for Organic Carbon (OC) using a Walkley and Black method, Total Nitrogen (TN) using Kjeldhal method, Available Phosphorus (Av. P) using Olsen metal method, Available potassium (Av. K) using Morgan's extraction method, $\mathrm{PH}$ using $\mathrm{PH}$ meter in water suspension with soil to water ratio 1:2:5, EC (Electrical conductivity) using electro conductivity meter, CEC (Cat ion exchangeable capacity) using Ammonium Acetate (1 M NH4OAC).

Bulk density is usually expressed in mega grams per cubic metre $(\mathrm{Mg} / \mathrm{m} 3)$ but the numerically equivalent units of $\mathrm{g} / \mathrm{cm}^{3}$ and $\mathrm{t} / \mathrm{m}^{3}$ are also used $\left(1 \mathrm{Mg} / \mathrm{m}^{3}=1 \mathrm{~g} / \mathrm{cm}^{3}=1 \mathrm{t} / \mathrm{m}^{3}\right)($ Cresswell and Hamilton, 2002).

Soil volume

Soil volume=ring volume

To calculate the volume of the ring:

i. Measure the height of the ring with the ruler in $\mathrm{cm}$ to the nearest $\mathrm{mm}$.

ii. Measure the diameter of the ring and halve this value to get the radius (r).

$$
\text { iii. Ring volume }(\mathrm{cm} 3)=\pi \times \mathrm{r}^{2} \times \text { ring height }
$$

Ring radius $=5.73 \mathrm{~cm}$ and ring height $=8 \mathrm{~cm}$

Ring volume $=3.14 \times 5.73 \times 5.73 \times 8=824.7 \mathrm{~cm} 3$

Dry soil weight

To calculate the dry weight of the soil:

i. Weigh an ovenproof container in grams (W1).

ii. Carefully remove the all soil from the bag into the container. Dry the soil for 10 minutes in the microwave, or for 2 hours in a conventional oven at $105^{\circ} \mathrm{C}$.

iii. When the soil is dry weigh the sample on the scales (W2).

$$
\text { iv. Dry soil weight }(\mathrm{g})=\mathrm{W} 2-\mathrm{W} 1
$$

Finally, Bulk density was calculated as follows;

$$
\text { Bulk density }\left(\mathrm{g} / \mathrm{cm}^{3}\right)=\frac{\text { Dry soil weight }(\mathrm{g})}{\text { Soil volume }\left(\mathrm{cm}^{3}\right)}
$$

\subsubsection{Tree Uses Analysis}

Use value index technique was used to identify and prioritize the important trees based on the uses mentioned by the farmers (Phillips and Gentry, 1993).

$$
\mathrm{UV}=\Sigma \mathrm{Ui} / \mathrm{n}
$$

Where: Ui is the number of uses mentioned by each respondent for a given species, $\mathrm{n}$ is the total number of respondents and stands for summation. The species will be then ranked basing on the overall use value. 
Important diversity measurement indice, Shannon index was used to calculate richness and abundance of the vegetation respectively. Shannon diversity indices will be estimated as Magurran (1988);

$$
\mathrm{H}^{\prime}=-\Sigma \text { pi lnpi }
$$

Where pi is the proportion of individuals composed of species i.

Shannon diversity index $\left(\mathrm{H}^{\prime}\right)$ is high when the relative abundance of the different species in the sample is even, and decreases when few species are more abundant than the others. It is based on the theory that when there are many species with even proportions, the uncertainty that a randomly selected individual belongs to a certain species increases and thus the diversity. As a measure of heterogeneity, Shannon's index takes into account the evenness of abundance of species [24].

Finally soil data's, tree utilization data's and diversity data's were adjusted to MINITAB 17 and analyzed with appropriate analytical methods.

\section{Results and Discussion}

\subsection{Socio-economic Characteristics of Warja Watershed}

\subsubsection{Household Characteristics of the Respondents}

The results of these socioeconomic characteristics of households are helpful in exploring the communities' infrastructures and resources need for planning future intervention of watershed management and could determine the extent to which the community could adopt the future intervention that might be useful in developing a plan for commencing community development work. The results from household survey revealed the average age of the respondents was 45 with a standard deviation of 15.09. The family size of the sampled households on average was six. The largest frequency in family size is four family members per household, which was about $5 \%$ of the sample households' family size. The sampled household education level in the study area ranges from illiterate to complete secondary school. The total land size of each household mostly consists of the cropland, grazing land, and homegardens. The average farmland size was 1.9 hectare with the range of 0.25 to 4 hectare whereas about $25 \%$ of the households have farmland ranging from 0.25 to 1 hectare (table 2).

Of the total respondents of the watershed $42.97 \%$ are occupants. According to the survey result, the minimum and maximum family size of the sample farm households was 2 and 16 respectively (table 2 ).

The respondents are divided into three age groups (i.e. up to 15,16 to 64 , and above 64 years of age). The idea behind these classes is that the middle group (16-64 years) is the most productive age group in farming. As age is one of the vital characteristics of the society which plays a significant role in any type of employment pattern, mobility and any kind of activity performances, particularly in agriculture, as the use of child labor on farm activities mostly prevail.
Table 2. Household respondents age characteristic in the Warja watershed $(N=63)$.

\begin{tabular}{llll}
\hline $\begin{array}{l}\text { Household } \\
\text { characteristics }\end{array}$ & $\begin{array}{l}\text { Unit of } \\
\text { Measurement }\end{array}$ & $\begin{array}{l}\text { Observed } \\
\text { range }\end{array}$ & $\begin{array}{l}\text { Average } \\
\text { age }\end{array}$ \\
\hline Age & Year & $22-75$ & 45 \\
Household family size & Numbers & $2-16$ & 6 \\
Household family by age categories & & \\
1-15 male & Numbers & $0-6$ & 1.76 \\
1-15 female & Numbers & $0-7$ & 1.62 \\
16-64 male & Numbers & $0-8$ & 2.25 \\
16-64 female & Numbers & $0-12$ & 1.83 \\
Greater than 64 male & Numbers & $0-1$ & 0.64 \\
Greater than 64 female & Numbers & $0-1$ & 0.11 \\
\hline
\end{tabular}

Majority of the sample farmers $(98.5 \%)$ owned farm lands with varies size ranging from 0.25 to 4 hectare, and on average 1.9 hectare of land holding (figure 2 and table 3 ).

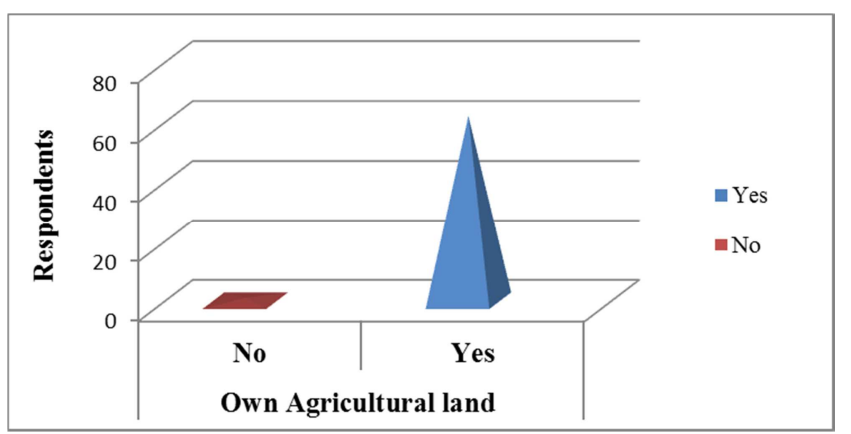

Figure 2. Households owing agricultural land.

Table 3. Household land holding, $(N=63)$.

\begin{tabular}{llll}
\hline $\begin{array}{l}\text { Household } \\
\text { characteristics }\end{array}$ & $\begin{array}{l}\text { Unit of } \\
\text { measurement }\end{array}$ & $\begin{array}{l}\text { Observed } \\
\text { range }\end{array}$ & Average \\
\hline Total land size & Hectare & $0.25-4$ & 1.9 \\
Education & Grade & $0-12$ & 4 \\
\hline
\end{tabular}

Agriculture (Working on farm) was the principal occupation of $98.4 \%$ of the economically active population of Warja watershed in 2017, although only about $22.4 \%$ of the respondents Work on farm as a Secondary occupation. Working on the farm includes crop production activities and rearing of the livestock's. Few households were also engaged on off-farm activities, another livelihood for the farmers in the watershed. The common types of off-farm income generating activities are petty trade and working as daily labor. About $17.9 \%$ of households in the area were involved in these income generating activities in addition to agricultural practices.

Table 4. Households means of livelihoods in the Warja watershed ( $n=63)$.

\begin{tabular}{lll}
\hline Occupation category & Frequency & $\begin{array}{l}\text { Percentage } \\
\text { (\%) }\end{array}$ \\
\hline \multirow{2}{*}{ Primary occupation } & Working on farm & 98.4 \\
& Casual farm labor & 1.6 \\
& Working on farm & 22.4 \\
& Casual farm labor & 6.1 \\
\multirow{5}{*}{ Secondary occupation } & Salaried/Wage labor (formal & 20.4 \\
& employment) & 12.2 \\
& Other & 38.8 \\
\hline
\end{tabular}




\subsubsection{Trends and Constraints of Crop Production in the Warja Watershed}

Crop production is one of the major agricultural activities undertaken by community in the Warja watershed (Table 5). The crops grown in the watershed were Maize, Wheat, Teff and Barley, Harricotbean and Sorghum. Maize and wheat were the major grown crops while sorghum was the Lesley grown one. These crops have been produced for the purpose of home consumption and seed at most while a few are sold in local markets as they came after threshing. The assessment conducted for the two cropping years showed there has been no common use of the crops varieties with their recommended technology package. In addition to these gaps, other external factors of production worsened the expected crops yield.

Table 5. Major crop types grown in two cropping year in the Warja Watershed.

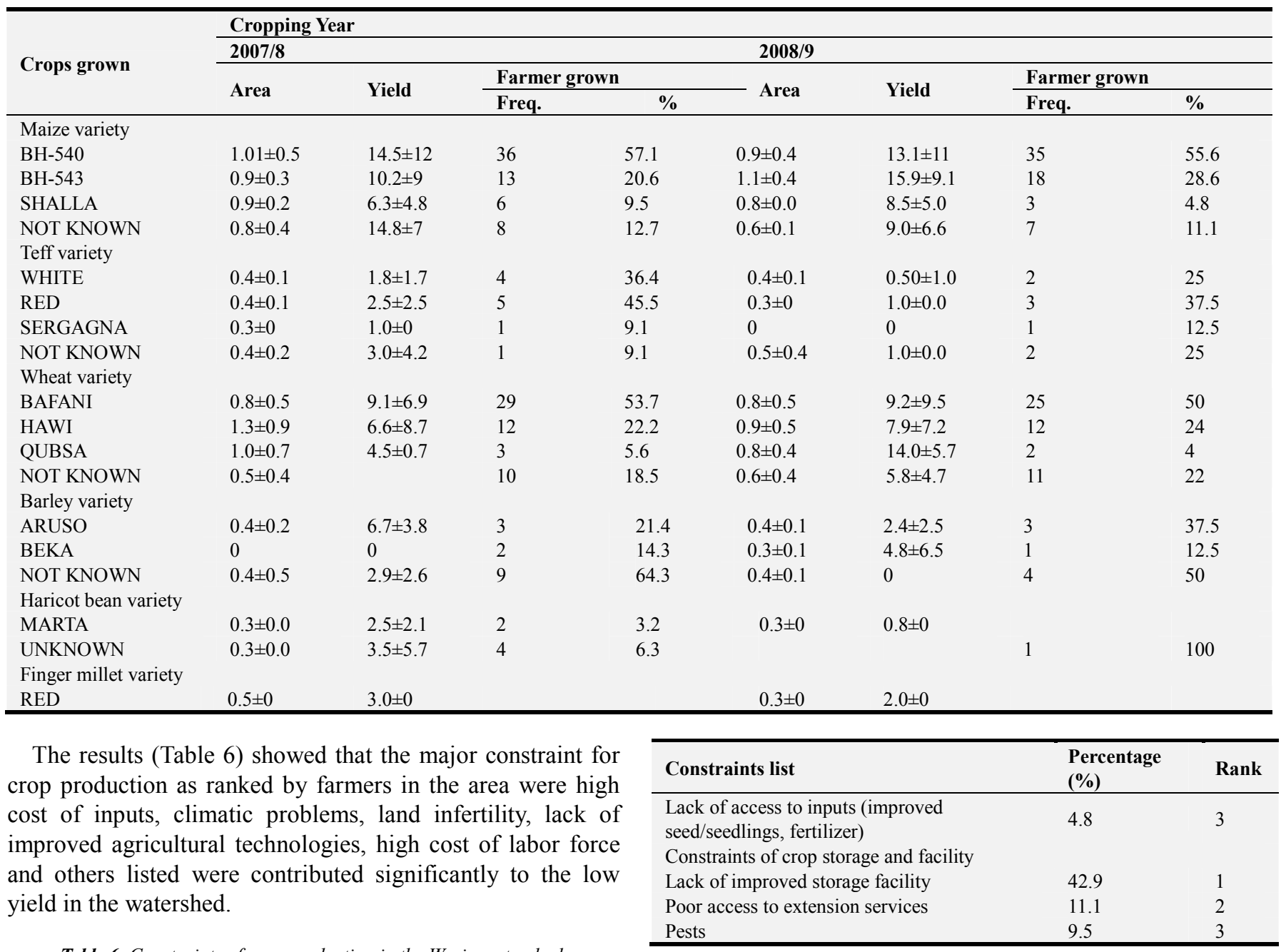

Table 6. Constraints of crop production in the Warja watershed.

\begin{tabular}{lll}
\hline Constraints & Percentage (\%) & Rank \\
\hline High cost of inputs & 65.08 & 1 \\
Climatic problem & 58.7 & 2 \\
Lack of improved agricultural & 19.0 & 4 \\
mechanization technologies & 17.46 & 5 \\
High cost of labor force & 15.87 & 6 \\
Poor access to extension services & 11.1 & 3 \\
Land infertility & 6.3 & 7 \\
Unavailability of inputs on time & 4.80 & 8 \\
Disease and pests & 3.20 & 9 \\
Lack of access to credit services & & \\
\hline
\end{tabular}

Table 7. Other major constraints related to crop production.

\begin{tabular}{lll}
\hline Constraints list & $\begin{array}{l}\text { Percentage } \\
(\mathbf{\% )}\end{array}$ & Rank \\
\hline Constraints of Crop marketing & & \\
Lack of market information & 52.4 & 1 \\
Market fluctuation & 38.1 & 2 \\
\hline
\end{tabular}

The majority of household respondents' perceived that crop production in the area is decreasing due to lack of access to inputs and climatic problem (frequently changing weather condition) (figure 3 and table 6).

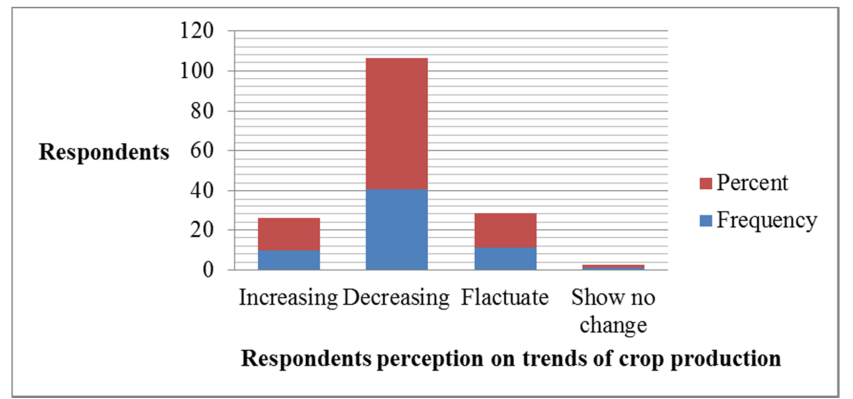

Figure 3. Trends of crops in the selected Warja watershed. 


\subsubsection{Livestock Production and Feeding Source Characteristics in the Warja Watershed}

Farmers in the watershed have low to moderated livestock population. Accordingly Local breed cow ranged from 1-7 and $0-12$ with the average of 2 and Local breed sheep and goat ranged from 1-10 and 1-20 and with average of 4 and 5 respectively although very few number of cross breeds livestock population is observed (table 8). The major livestock feeding source in the selected Warja watershed are grazing land and aftermath of croplands, although it exceeds the carrying capacity of the existing livestock population they are available in the area. Various food crops, mainly cereals and pulse crop residues were also the commonly used feed sources for all livestock categories during the dry season and private grazing land near the farmers' homestead and small plots of grazing lands at the edge of croplands were the main source of feed for their livestock at wet season. Animals were restricted to the smaller area near the homestead during the wet season because it overlaps with rain-fed crop growing seasons. Besides, animals were primarily fed on weeds harvested from within the cropland, green grasses and thin out crops, as it is also confirmed by the secondary information (Table 9). Industrial by-products have not been used by farmers in mostly in the area during wet seasons because this time is characterized by availability amble feed sources. Due to challenges related with unaffordable prices of industrial by-products by smallholders, they have rarely used it for animals affected by feed shortage during the dry season.

The feeding source in the study watershed was dominantly pasture land, vegetable waste, fodder trees/shrubs, weeds, thin out crops and crop residue $(93.65 \%)$ followed by all industrial by products and concentrate feed which cover $6.35 \%$ of the total feed source in the area. The contribution of communal grazing land sole was lower as result of shortages of grazing land (bush and scramble tree covered) occur due to expansion of crop lands due to increased population as well as degradation of the land current local community holds.

Table 8. Farm animals' resources in the Warja watershed.

\begin{tabular}{llll}
\hline \multirow{2}{*}{ Livestock type } & \multicolumn{3}{l}{ Total number owned by the household } \\
\cline { 2 - 4 } & Mean & Minimum & Maximum \\
\hline Local breed cow & 2.22 & 1 & 7 \\
Local breed oxen & 1.84 & 1 & 5 \\
Local breed calves & 1.87 & 0 & 7 \\
Local breed heifers & 1.68 & 0 & 6 \\
Local breed bull & 1.18 & 0 & 3 \\
Local breed goat & 4.92 & 1 & 20 \\
Local breed sheep & 4.08 & 0 & 10 \\
Local breed chicken & 5.95 & 1 & 12 \\
Donkey & 2.14 & 1 & 15 \\
Horse & 1.00 & 0 & 2 \\
Mule & .00 & 0 & 0 \\
Cross breed cow & .50 & 0 & 1 \\
Cross breed oxen & .33 & 0 & 1 \\
Cross breed calves & .75 & 0 & 2 \\
Cross breed heifers & .33 & 0 & 1 \\
Cross breed bull & .00 & 0 & 0 \\
Cross breed goat & 1.00 & 0 & 3 \\
Breed sheep & .67 & 0 & 2 \\
Cross breed chicken & .00 & 0 & 0 \\
\hline
\end{tabular}

Table 9. Characteristics of respondent on livestock feed system in the Warja watershed.

\begin{tabular}{llc}
\hline Categories & Frequency \\
\hline Own grazing land & Percent (\%) & 8 \\
Have pasture land & 55 & 12.7 \\
Don't have pasture land & 87.3 \\
Source of animal feed & 4 \\
Industrial by-products and Concentrate feed & 59 & 6.4 \\
Pasture land, vegetable waste, fodder trees/shrubs, Weeds, thin out crops and crop residue & 63.7 \\
Feel no enough animal feed & 0 \\
I believe that feed is enough & 0 \\
\hline
\end{tabular}

Farmers have mentioned some constraints affecting livestock production in their area and ranked them based on their severity. Accordingly, the most common constraints of animal production in the area were lack of improved breed and un availability of feed because of drought and lack of improved forage and/or fodder species (table 10).

Table 10. Constraint analysis of animal production in the Warja watershed.

\begin{tabular}{lll}
\hline Constraints list & Percentage (\%) & Rank \\
\hline Animal breeding constraint & & \\
Animal feed shortage & 46.0 & 1 \\
Lack of improved genotype & 38.0 & 2 \\
Disease & 30.2 & 3 \\
Animal feed constraint & & \\
Un availability of feed & 39.7 & 1 \\
Climatic problem/drought & 31.7 & 2 \\
Lack of access to improved forage/fodder & 12.7 & 3 \\
seed/seedlings & & \\
\hline
\end{tabular}

\begin{tabular}{lll}
\hline Constraints list & Percentage (\%) & Rank \\
\hline $\begin{array}{l}\text { Poor access to extension services } \\
\text { Livestock fattening constraint }\end{array}$ & 3.2 & 4 \\
Lack of improved breed & 36.5 & 1 \\
Unavailability of feed & 23.8 & 2 \\
Lack of access to credit services & 14.3 & 3 \\
Poor access to extension services & 7.9 & 4 \\
High interest rate & 6.3 & 5 \\
Lack of improved agricultural technologies & 6.3 & 6 \\
(mechanization) & 1.6 & 7 \\
Un availability of inputs on time & 1.6 & 8 \\
Shortage of labor force & & \\
Dairy production constraints & 54.0 & 1 \\
Lack of improved breed & 23.8 & 2 \\
Un availability of feed & 11.1 & 3 \\
Lack of improved dairy technologies & 3.2 & 4 \\
Lack of access to credit services & 1.6 & 5 \\
Shortage of labor force & 1.6 & 6 \\
High interest rate & & \\
Livestock marketing constraints & & \\
\hline
\end{tabular}




\begin{tabular}{lll}
\hline Constraints list & Percentage (\%) & Rank \\
\hline Market fluctuation & 39.7 & 1 \\
Lack of market information & 34.9 & 2 \\
\hline
\end{tabular}

The results (Table 11) of baseline survey were indicated that in Warja watershed, beekeeping was practiced by few farmers ( 8 farmers out of 63 household respondents with too minimum number of farmers holding moveable frame) (table 11) and, consequently no attention was given in order to improve their income livelihood from the sale of honey and nutrition and employment opportunities. Although lack of beekeeping equipment's and farmer's awareness in solving constraints of beekeeping exist in the area, the few farmers holding honeybee colony have been getting significant honey production. As constraints poor access to extension services includes; Poor honey processing facilities, inadequate skills on improved beekeeping, inadequate skills of seasonal bee management, etc. (Table 11). So, improving these is about improving the production of honeybee in the watershed. Access to credit services (Table 11) is also important for farmers to establish modern production sites individually or as a group and also without such kind of facility farmers have no capacity to incur costs of the beehives.

Table 11. Beekeeping characteristics in the Warja watershed.

\begin{tabular}{llll}
\hline No. & Categories by beekeeping practices & Frequency & Percent (\%) \\
\hline \multirow{2}{*}{1} & Respondents having practices of beekeeping & 8 & 12.7 \\
& Traditional & 6 & 75 \\
2 & Movable frame & 2 & 25 \\
\hline
\end{tabular}

Table 12. Apiculture constraints analysis of Warja Watershed.

\begin{tabular}{lll}
\hline Constraints list & Percentage (\%) & Rank \\
\hline Poor access to extension services & 20.6 & 1 \\
Lack of improved bee technologies & 19.0 & 2 \\
Un availability of feed & 11.1 & 3 \\
Lack of access to credit services & 3.2 & 4 \\
Climatic problem/drought & 3.2 & 5 \\
Lack of access to improved forage seed and / seedlings) & 1.6 & 6 \\
Pest problem & 1.6 & 7 \\
\hline
\end{tabular}

\subsection{Bio-physical Resources Characteristics of Warja Watershed}

\subsubsection{Land uses of Warja Watershed}

Cultivated land covers the highest portion of area (Table 13 and Figure4) in the watershed while followed by open grazing area, mostly of hill slope.

Table 13. Land use types of Warja Watershed 2009 E. C.

\begin{tabular}{llll}
\hline No & Land use & Area_ha & Area_\% \\
\hline 1 & Cultivated land & 473.87 & 68.24 \\
2 & Closure Area & 54.44 & 7.84 \\
3 & Open Grazing area & 166.11 & 23.92 \\
& Total & 694.42 & 100 \\
\hline
\end{tabular}

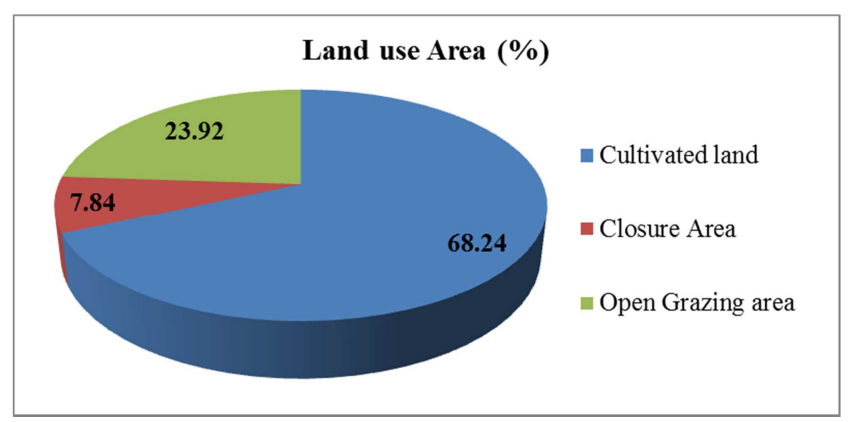

Figure 4. Land use/ cover of Warja Watershed.

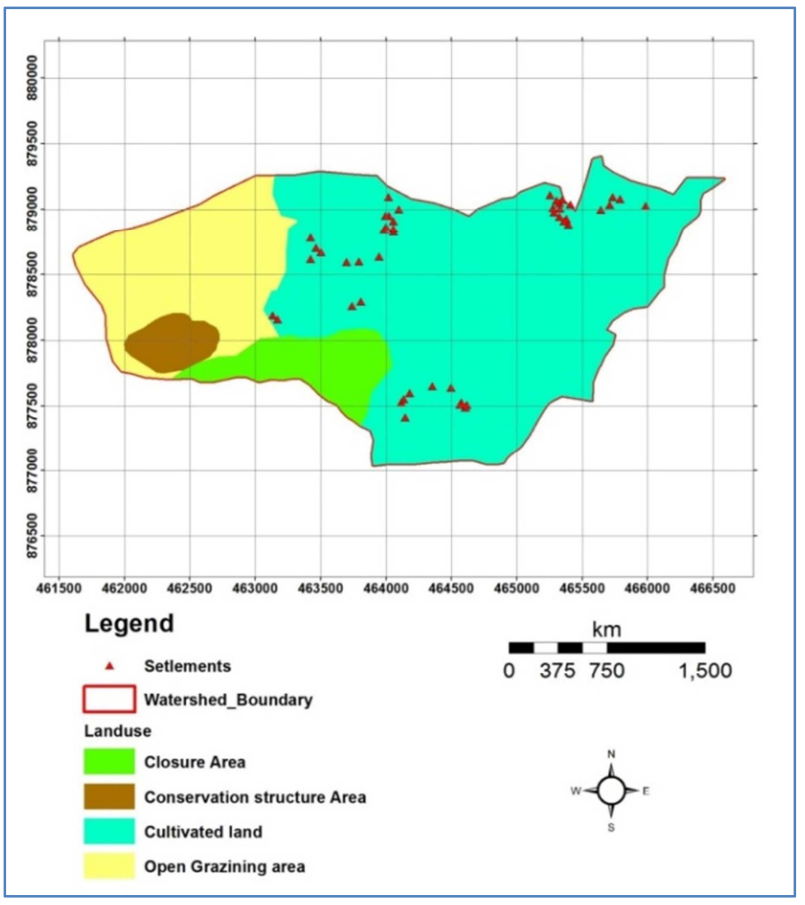

Figure 5. Land use/ cover Map of Warja Watershed.

\subsubsection{Topographic Characteristics of Warja Watershed} Location Map of Warja Watershed Warja watershed is located between $7^{\circ} 56^{\prime} 0^{\prime \prime}$ to $7^{\circ} 57.5^{\prime} 0^{\prime \prime}$ 
$\mathrm{N}$ latitude and $38^{\circ} 39^{\prime} 0^{\prime \prime}$ to $38^{\circ} 42^{\prime} 0^{\prime \prime}$ E longitude (Figure 6). Slope

Topography affects landscape by facilitating physically land cover changing problems like flooding, degradation, etc. based on steepens of slope and slope length. Slope gradient of Warja watershed ranges from 0 to more than 30 and the slope gradient of 2-5 and 5-10 cover the greatest in area coverage representing 204 ha and 145 ha respectively (table 14). This indicate that more of the watershed landscape might be exposed to extreme flooding at time of high rain fall occurrences which implies that the need of soil and water conservation structures for sound natural resources conservation in the area. This is agreed with the findings of [7] stating that the slope configuration provides few depositional sites within the hill slope. However, where excessive slope lengths occur, off slope transport of sediment (erosion) can be anticipated.

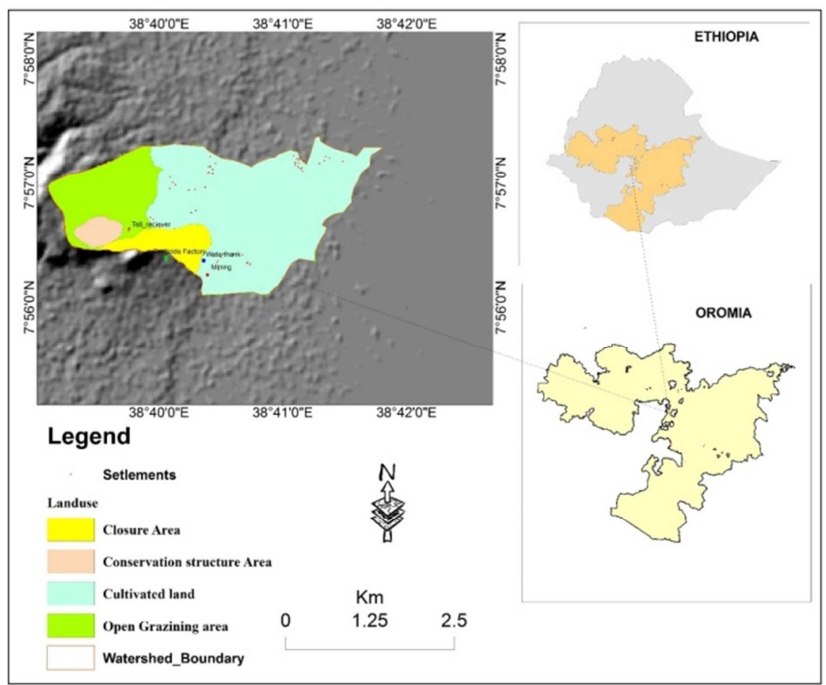

Figure 6. Map of Warja Watershed.

Table 14. Slope gradient of Warja watershed.

\begin{tabular}{lllll}
\hline No & Slope (\%) & Area_ha & Area_(\%) & Rank \\
\hline 1 & $0-1$ & 99 & 14 & 3 \\
2 & $1-2$ & 72 & 10 & 6 \\
\hline
\end{tabular}

\begin{tabular}{lllll}
\hline No & Slope (\%) & Area_ha & Area_(\%) & Rank \\
\hline 3 & $2-5$ & 204 & 29 & 1 \\
4 & $5-10$ & 145 & 21 & 2 \\
5 & $10-15$ & 86 & 12 & 4 \\
6 & $15-30$ & 75 & 11 & 5 \\
7 & $>=30$ & 12 & 2 & 7 \\
\hline
\end{tabular}

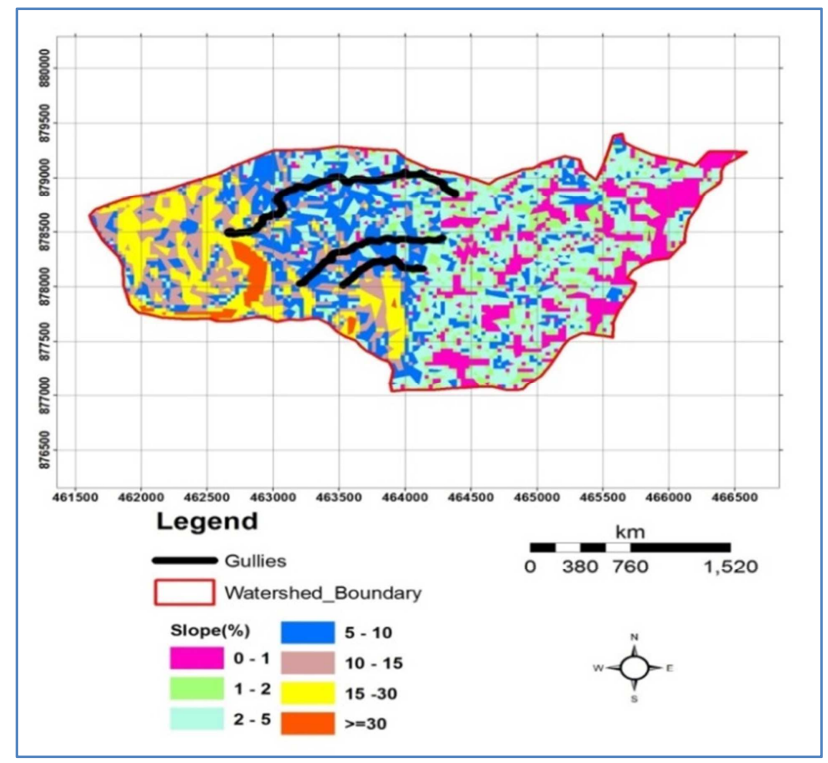

Figure 7. Slope Map of Warja Watershed.

Climate of the Watershed

In the periods of five years the mean minimum temperature of the area obtained maximum value in May and June almost $15^{\circ} \mathrm{C}$ while lowest value $9^{\circ} \mathrm{C}$ in December (table 15). When say Minimum temperature is actually about hot nights and Daily temperature observations show significantly much large increasing trends in the frequency of hot nights according to UNDP country portal [1]. The result is almost similar with the observation did in Amhara and Tigray parts of Ethiopia in the periods of 1980-2010. These are clearly an indication of warming nights over the years and shows those seasons are getting hotter in recent years [17].

Table 15. Minimum Temperature (2012-2016).

\begin{tabular}{|c|c|c|c|c|c|c|}
\hline Variable & Mean & Variance & Min & Max & Median & Range \\
\hline January & $10.5 \pm 2.4$ & 5.972 & 8 & 14.4 & 9.8 & 6.4 \\
\hline February & $10.96 \pm 1.6$ & 2.603 & 9.1 & 13.2 & 10.6 & 4.1 \\
\hline March & $12.5 \pm 1.5$ & 2.32 & 11.4 & 15.1 & 12.2 & 3.7 \\
\hline April & $14.3 \pm 1.8$ & 3.177 & 12.6 & 16.9 & 13.5 & 4.3 \\
\hline May & $15.3 \pm 0.7$ & 0.538 & 14.3 & 16 & 15 & 1.7 \\
\hline June & $15.26 \pm 1.02$ & 1.048 & 14.2 & 16.8 & 15.2 & 2.6 \\
\hline July & $14.84 \pm 0.82$ & 0.668 & 13.6 & 15.7 & 15.1 & 2.1 \\
\hline August & $14.4 \pm 0.81$ & 0.655 & 13.4 & 15.3 & 14.8 & 1.9 \\
\hline September & $13.36 \pm 1.17$ & 1.373 & 11.8 & 14.6 & 13.3 & 2.8 \\
\hline October & $11.22 \pm 1.34$ & 1.807 & 9.7 & 12.7 & 11 & 3 \\
\hline November & $10.36 \pm 1.35$ & 1.823 & 9.1 & 12.4 & 9.9 & 3.3 \\
\hline December & $9.08 \pm 2.48$ & 6.137 & 6.2 & 12.8 & 9.3 & 6.6 \\
\hline
\end{tabular}

In the periods of five years the maximum temperature of the area obtained mean minimum value in July and August having a value of $25.5^{\circ} \mathrm{C}$ while the rest of the months obtained maximum value between $28^{\circ} \mathrm{C}$ to $32^{\circ} \mathrm{C}$. When see as a single months maximum value $35^{\circ} \mathrm{C}$ scored in March while $23.6^{\circ} \mathrm{C}$ in July (Table 16 ). 


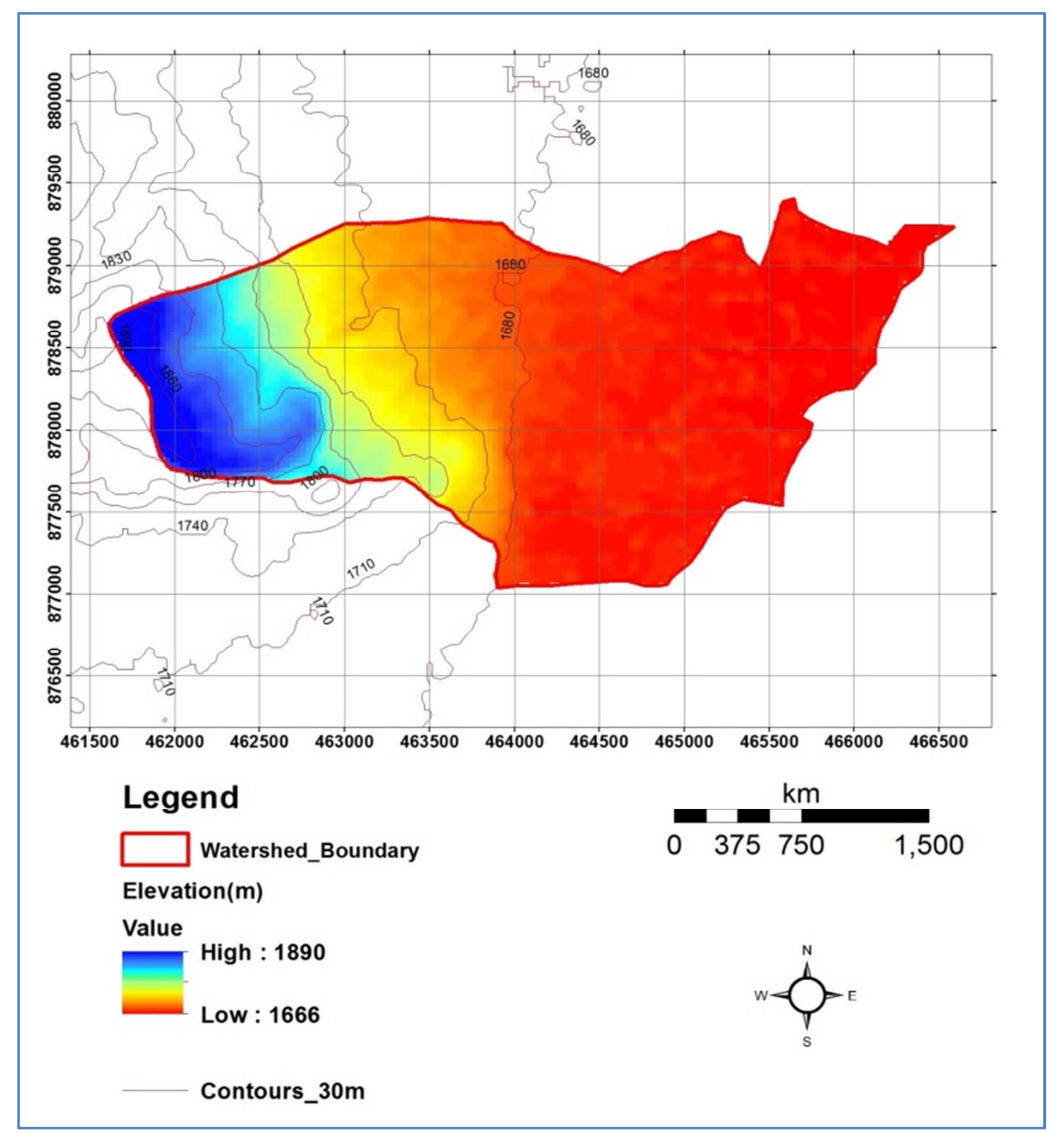

Figure 8. Elevation Map of Warja Watershed.

Table 16. Maximum Temperature (2012-2016).

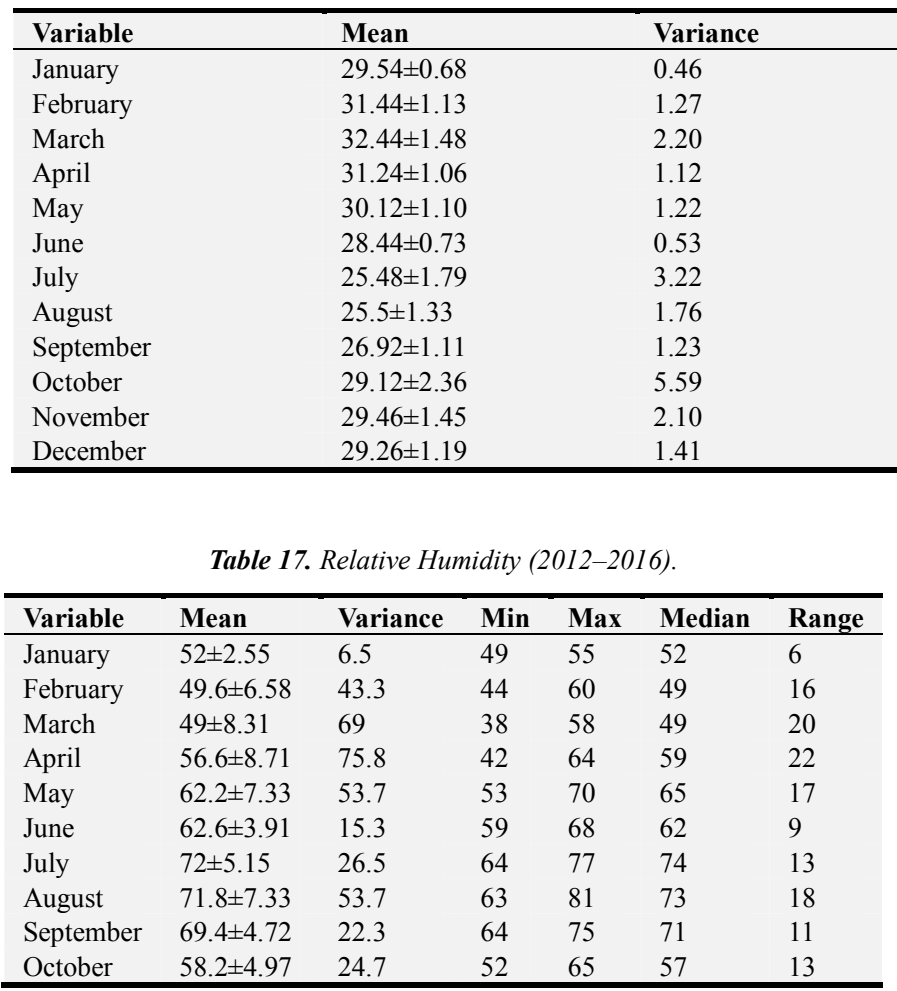

\begin{tabular}{llll} 
Min & Max & Median & Range \\
\hline 28.9 & 30.6 & 29.5 & 1.7 \\
29.7 & 32.7 & 31.8 & 3 \\
30.9 & 34.9 & 32 & 4 \\
29.7 & 32.6 & 31.2 & 2.9 \\
29 & 31.7 & 29.6 & 2.7 \\
27.3 & 29.3 & 28.5 & 2 \\
23.6 & 27.9 & 26 & 4.3 \\
24.1 & 26.9 & 25.1 & 2.8 \\
25.8 & 28.2 & 26.8 & 2.4 \\
27.2 & 33.1 & 28 & 5.9 \\
28.4 & 32 & 28.9 & 3.6 \\
28.1 & 31 & 28.9 & 2.9 \\
\hline
\end{tabular}

\begin{tabular}{lllllll}
\hline Variable & Mean & Variance & Min & Max & Median & Range \\
\hline November & $53 \pm 4.24$ & 18 & 49 & 59 & 53 & 10 \\
December & 51.82 .59 & 6.7 & 49 & 55 & 51 & 6 \\
\hline
\end{tabular}

The result (Table 18) showed the area obtained $65 \mathrm{~mm}$ average rain fall in five years (2012-2016) and $121 \mathrm{~mm}$ average rainfall in five years (2012-2016) during cropping seasons (from May-September). These is almost closer to the average result obtained $63 \mathrm{~mm}$ rain in ten (10) years (19962005 ) and $100 \mathrm{~mm}$ average result in cropping seasons (MaySeptember) by [22]. 
Table 18. Rain Fall of Warja Watershed (2012-2016).

\begin{tabular}{|c|c|c|c|c|c|c|}
\hline Variable & Mean & Variance & Min & Max & Median & Range \\
\hline January & $7.28 \pm 15.73$ & 247.29 & 0 & 35.4 & 0 & 35.4 \\
\hline February & $14 \pm 27.14$ & 736.52 & 0 & 62.3 & 1.1 & 62.3 \\
\hline March & $32.82 \pm 26.45$ & 699.62 & 2.9 & 75.5 & 28.7 & 72.6 \\
\hline April & $60.5 \pm 61.39$ & 3768.19 & 0 & 154.1 & 43.4 & 154.1 \\
\hline May & $101.14 \pm 51.11$ & 2612.45 & 37.9 & 160.7 & 81.7 & 122.8 \\
\hline June & $95.82 \pm 55.30$ & 3058.63 & 22.4 & 159.7 & 111.1 & 137.3 \\
\hline July & $214.84 \pm 72.82$ & 5302.13 & 147.5 & 320.4 & 206.1 & 172.9 \\
\hline August & $111.24 \pm 46.34$ & 2146.99 & 51.2 & 161.4 & 100.8 & 110.2 \\
\hline September & $80.54 \pm 70.64$ & 4989.81 & 1.6 & 195.6 & 66.5 & 194 \\
\hline October & $57.96 \pm 97.31$ & 9468.38 & 0 & 228 & 9.7 & 228 \\
\hline November & $0.58 \pm 1.30$ & 1.68 & 0 & 2.9 & 0 & 2.9 \\
\hline December & $0 \pm 0$ & 0 & 0 & 0 & 0 & 0 \\
\hline
\end{tabular}

Table 19. Evaporation status of Warja Watershed (2012-2016).

\begin{tabular}{|c|c|c|c|c|c|c|}
\hline Variable & Mean & Variance & Min & Max & Median & Range \\
\hline January & $7.58 \pm 0.89$ & 0.80 & 6.5 & 8.45 & 7.68 & 1.95 \\
\hline February & $8.17 \pm 1.13$ & 1.28 & 6.77 & 9.5 & 8.21 & 2.73 \\
\hline March & $8.43 \pm 1.38$ & 1.90 & 7.47 & 10.47 & 7.89 & 3 \\
\hline April & $7.66 \pm 1.70$ & 2.90 & 6.19 & 9.69 & 7.39 & 3.5 \\
\hline May & $6.33 \pm 0.83$ & 0.68 & 5.34 & 7.36 & 6.31 & 2.02 \\
\hline June & $6.96 \pm 0.73$ & 0.53 & 5.9 & 7.52 & 7.21 & 1.62 \\
\hline July & $5.11 \pm 0.70$ & 0.49 & 4.18 & 5.79 & 5.23 & 1.61 \\
\hline August & $4.92 \pm 0.62$ & 0.38 & 4.26 & 5.56 & 4.92 & 1.3 \\
\hline September & $4.92 \pm 0.42$ & 0.17 & 4.6 & 5.53 & 4.78 & 0.93 \\
\hline October & $5.88 \pm 0.84$ & 0.71 & 5.28 & 7.12 & 5.55 & 1.84 \\
\hline November & $6.46 \pm 0.30$ & 0.09 & 6.06 & 6.73 & 6.52 & 0.67 \\
\hline December & $6.97 \pm 0.57$ & 0.32 & 6.39 & 7.7 & 6.90 & 1.31 \\
\hline
\end{tabular}

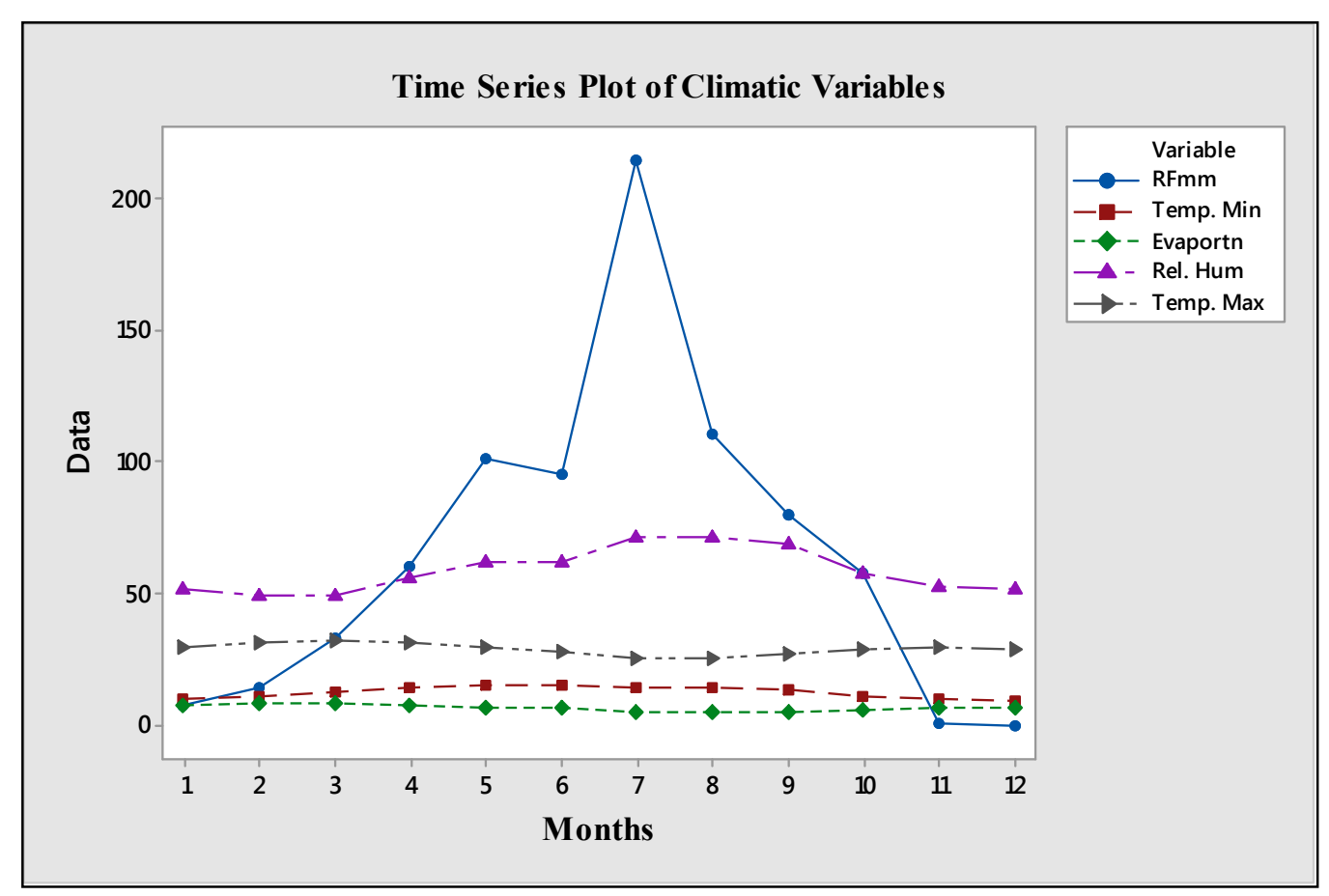

Figure 9. Time series of climate variables.

\subsubsection{Soil Properties of the WATERSHED}

The proportion of Watershed soil texture is $72.6 \%$ sand, $21.6 \%$ silt, $6 \%$ under category of sandy loam (Table 20 ). This is similar with what [19] stated most of the areas soil texture is under the category of sandy loam.
Table 20. The soil textural classification of Warja Watershed.

\begin{tabular}{lll}
\hline Textures & Mean & Std Dev. \\
\hline \% Sand & 72.6 & 8.8 \\
\% Silt & 21.6 & 6.8 \\
\% Clay & 5.9 & 3.8 \\
\hline
\end{tabular}


The recorded mean soil bulk density of the watershed was $0.18 \pm 0.02$ (mean \pm std). This means the soil is a bulk soil that is important for tree root development. The critical value of bulk density for restricting root growth varies with soil type [20] but in general bulk densities greater than $1.6 \mathrm{~g} / \mathrm{cm} 3$ tend to restrict root growth [21].

The range of the soil $\mathrm{PH}$ in the watershed falls between the optimum ranges 6-7. EC was also in its normal range (less than $1 \mathrm{dS} / \mathrm{m})$. The result agrees with suitability indicated by [18] reported that EC less than one is suitable for plant growth. [5] described guidelines for interpreting phosphorus (P) for neutral and acid soils puts the fertility level of the soil as Low (<20), Medium (20-40), High (40-100), Excessive
$(>100)$; for potassium $(\mathrm{K})$ puts the fertility level of the soil as Very low (<75), Low (75-150), Medium (150-250), High $(250-800)$ and very high $(>800)$ and Nitrogen (ppm) levels in soil test result as low $(<10)$, medium $(10-20)$, high (20-30), Excessive ( $>30)$. Accordingly, the watershed soil has low Av. $\mathrm{p}$ and high Av. K.

Overall average CEC of the watershed was $16 \mathrm{meq} / 100 \mathrm{~g}$ (milli-equivalents per 100 grams of soil) and it was almost the same with the upper maximum CEC $15 \mathrm{meq} / 100 \mathrm{~g}$ reported by [25] for fine textured soils. This could be true since the textural soil type of the watershed was sandy loam (Table 20). This all could help any intervening body as a base line for important improvements.

Table 21. Soil chemical properties of Warja Watershed per land uses.

\begin{tabular}{|c|c|c|c|c|c|c|c|c|c|}
\hline Land Uses & EC & PH & Av. P & CEC & Av. K & OC & $\%$ Sand & $\%$ Silt & \% Clay \\
\hline Cultivated Land & $0.15 \pm 0.07$ & $7.4 \pm 0.6$ & $3.86 \pm 1.8$ & $18.5 \pm 4.8$ & $663.55 \pm 126.8$ & $1.15 \pm 0.2$ & $68.9 \pm 10.3$ & $24.1 \pm 7.7$ & $7 \pm 4.5$ \\
\hline Grazing Land & $0.22 \pm 0.06$ & $7.6 \pm 1.07$ & $2.9 \pm 1.43$ & $12.7 \pm 6.08$ & $650.8 \pm 133.9$ & $1.6 \pm 0.6$ & $76.9 \pm 3.7$ & $18.9 \pm 4.2$ & $4.2 \pm 1.8$ \\
\hline Protected Land & $0.16 \pm 0.08$ & $6.67 \pm 0.06$ & $3.4 \pm 1.4$ & $17.95 \pm 1.196$ & $653.3 \pm 105$ & $2.6 \pm 0.28$ & $77.9 \pm 00$ & $16.9 \pm 4.2$ & $5.2 \pm 1.2$ \\
\hline
\end{tabular}

Table 22. Major soil fertility improvement constraints.

\begin{tabular}{|c|c|c|c|}
\hline No. & Constraints list & Percentage \% & Rank \\
\hline 1 & Fertility of Cultivable land declined & 30.2 & 1 \\
\hline 2 & Lack of improved agricultural technologies (mechanization) & 19.0 & 2 \\
\hline 3 & Lack of access to inputs (fertilizer) & 9.5 & 3 \\
\hline 4 & Climatic problem/drought & 6.3 & 4 \\
\hline
\end{tabular}

\subsubsection{Erosion Status of the Watershed}

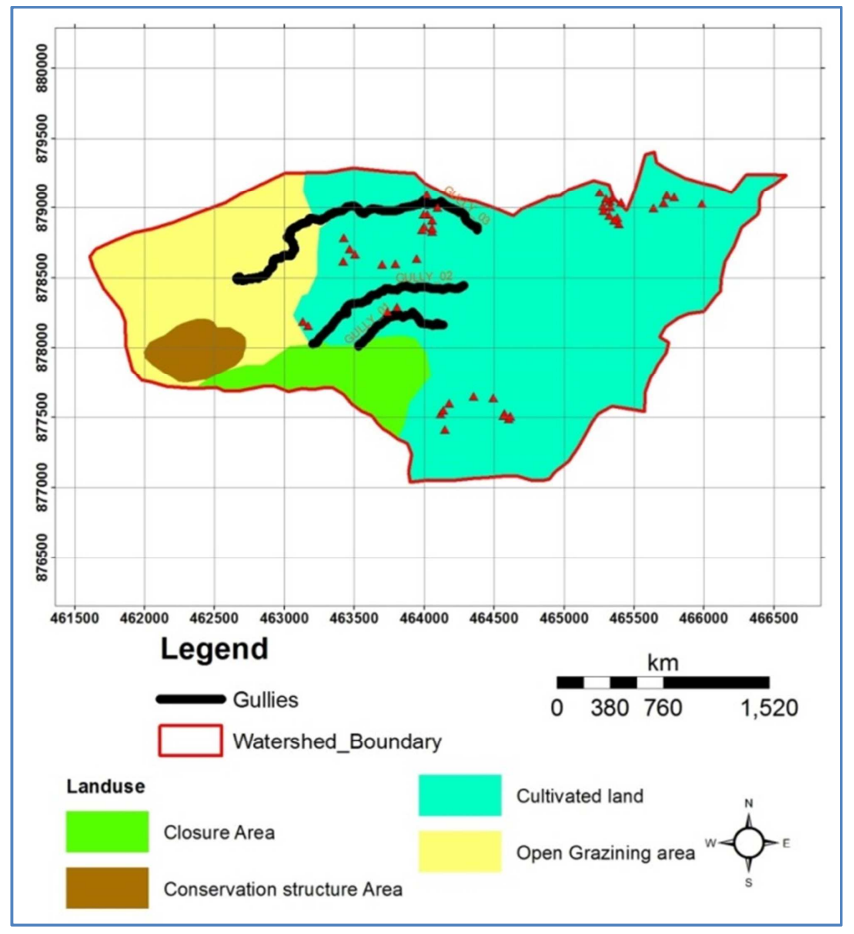

Figure 10. Digitized gullies in the Warja Watershed.

Many rills that has prominent role in the development of gullies were observed in the watershed. Accordingly, three big gullies (Figure 10) were formed because of water erosion in the watershed. According to the rangeland health and pasture condition (2003) scoring models, Reduction of vegetative cover causes increased surface runoff and often leads to accelerated erosion. Rills and gullies develop, followed by larger flow concentrations. Runoff is closely linked to chemical and nutrient cycling, erosion, and contaminant transport. It can also be a sensitive indicator of ecosystem change. Plant community types and the character of vegetative cover are one of the factors that determine the rate and areal distribution of runoff from a watershed. For every watershed and site within the watershed, there exists a critical point of deterioration resulting from surface erosion.

Different physical and bio-physical soil and water conservation measures were recorded in the watershed. Accordingly, Gabion dam in Gully, soil and stone bunds, Micro catchments like half-moon and V-shape with trees especially Acacia saligna were available in the watershed. The statuses of most structures were declined while few of them were under good performance for Acacia saligna tree obtained growth benefit because of stored water by the structure.

\subsubsection{Watershed Vegetation Diversity and Composition}

Knowing the distribution and the slopes on which trees exist in the watershed help for preparing intervention plan for massive tree planting. Hence, Acacia tortilis and Albizia lobbeck (Table 23) were trees highly distributed in the watershed. 
Table 23. Distribution (\%) and slope of existence of woody tree/ shrub species in the watershed.

\begin{tabular}{|c|c|c|c|c|c|}
\hline No. & Species scientific name & Local name of spp. & Percent & Slope of existence & Growth status \\
\hline 1 & Acaia Saligna & & 6.90 & $10-30$ & tree \& bush \\
\hline 2 & Acacia tortilis & Dhaddacha & 27.59 & $0-10$ & tree \\
\hline 3 & Albiza lobbek & Qarxafaa & 17.24 & $0-30$ & tree \\
\hline 4 & Croton macrostachyus & Makkannisa & 3.45 & $2-5$ & tree \\
\hline 5 & Acacia negrii & Dodota & 10.34 & $5-30$ & tree $\&$ bush \\
\hline 6 & Acacia albida & Garbii & 6.90 & $0-2$ & tree \\
\hline 7 & Bridelia micrantha & Riga-arbaa & 3.45 & $5-10$ & bush \\
\hline 8 & Caparis tomentosa & Harangama & 3.45 & $10-15$ & bush \\
\hline 9 & Maytenus arbutifolia & Kombolcha & 3.45 & $15-30$ & bush \\
\hline 10 & Olea africana & Ejersa & 3.45 & $15-30$ & bush \\
\hline 12 & Acacia seyal & Waaccuu & 3.45 & $5-10$ & tree \\
\hline
\end{tabular}

Table 24. Mean richness of woody tree/ shrub species in the Watershed.

\begin{tabular}{|c|c|c|c|c|c|c|}
\hline No. & Trees scientific names & Trees local name & Mean & std. & Min & Max \\
\hline 1 & Acacia tortilis & Dhaddacha & 2.1 & 1.2 & 1.0 & 4.0 \\
\hline 2 & Acacia Saligina & & 6.0 & 1.4 & 5.0 & 7.0 \\
\hline 3 & Albiza lobbek & Qarxafaa & 3.3 & 2.6 & 1.0 & 9.0 \\
\hline 4 & Croton macrostachyus & Bakkanniisa & 1.0 & $*$ & 1.0 & 1.0 \\
\hline 5 & Acacia negrii & Doddota & 5.3 & 2.3 & 4.0 & 8.0 \\
\hline 6 & Acacia albida & Garbii & 4.0 & 0.0 & 4.0 & 4.0 \\
\hline 7 & Bridelia micrantha & Riga-arbaa & 1.0 & $*$ & 1.0 & 1.0 \\
\hline 9 & Maytenus arbutifolia & Kombolcha & 1.0 & $*$ & 1.0 & 1.0 \\
\hline 10 & Olea africana & Ejersa & 4.0 & $*$ & 4.0 & 4.0 \\
\hline 11 & Acacia seyal & Waaccuu & 1.0 & $*$ & 1.0 & 1.0 \\
\hline
\end{tabular}

Diversity is higher as the value is closer to 1 . Shannon Index consider the evenness and shown low diversity. Overall, few species were abundant than others and low species diversity recorded in the watershed (Table 25).

Table 25. Mean richness and diversity of woody tree/ shrub species in the watershed.

\begin{tabular}{llll}
\hline Variable & Mean & Min & Max \\
\hline Over all Richness & $3 \pm 2.24$ & 1 & 9 \\
\hline
\end{tabular}

\begin{tabular}{llll}
\hline Variable & Mean & Min & Max \\
\hline Shannon Index & $0.22 \pm 0.14$ & 0 & 0.4 \\
\hline
\end{tabular}

\subsubsection{Farmers Tree Use Preference}

Based on tree use preference by farmers (Figure 11) Acacia tortilis, Albizia lobbeck and Balanites aegyptiaca were among the most three species obtained the highest use value index. This helps any intervening bodies where to focus to increase the community benefit from these trees.

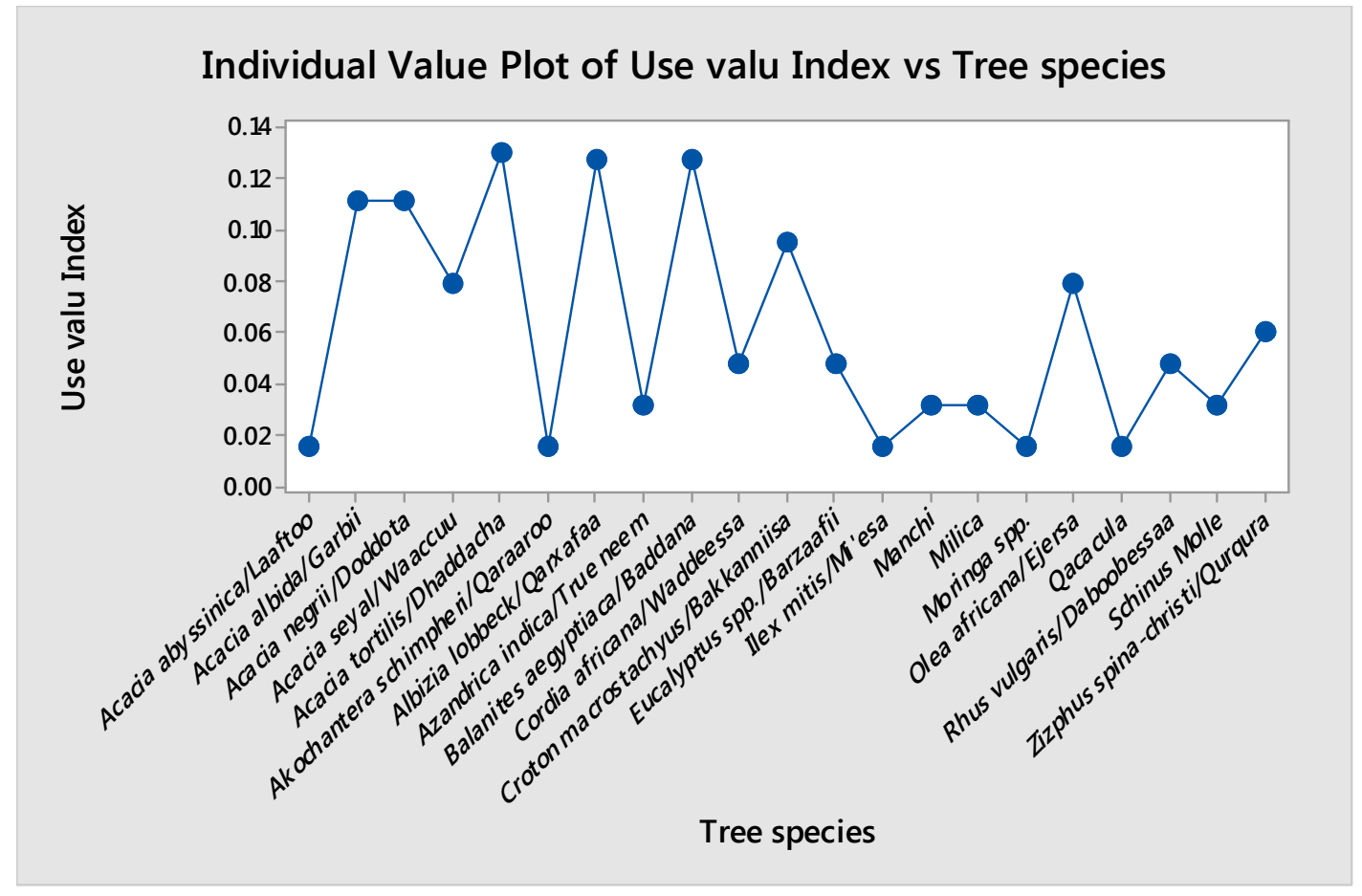

Figure 11. Use value Index of Tree species mentioned by respondents. 
Table 26. Different uses (\%) obtain from trees in the Watershed.

\begin{tabular}{|c|c|c|}
\hline No. & List of uses & Species category \\
\hline 1 & Shade & $\begin{array}{l}\text { Acacia albida }(3.2 \%) \text {, Acacia tortilis }(54 \%), \text { Acacia negrii }(3.2 \%) \text {, Balanites aegyptiaca }(14.3 \%) \text {, Albizia lobbeck } \\
\text { (7.9\%), Olea africana (1.6\%), Azadirachta indica (4.8\%), Croton macrostachyus }(3.2 \%) \text {, Cordia africana }(9.6), \\
\text { Schinus molle (3.2\%) }\end{array}$ \\
\hline 2 & Fodder & $\begin{array}{l}\text { Acacia tortilis (20.6\%), Acacia albida (1.6\%), Acacia negrii (15.9\%), Acacia seyal (1.6\%), Balanites aegyptiaca } \\
(28.6 \%) \text {, Albizia lobbeck (28.3\%), Zizphus spina-christi }(4.8 \%)\end{array}$ \\
\hline 3 & Medicine & Olea africana (1.6\%), Croton macrostachyus (1.6\%), Azadirachta indica (1.6\%) \\
\hline 4 & Firewood/Fuelwood & $\begin{array}{l}\text { Acacia tortilis (28.6), Acacia albida (1.6\%), Acacia negrii }(15.9 \%) \text {, Acacia abyssinica }(1.6 \%) \text {, Balanites aegyptiaca } \\
(19 \%) \text {, Acacia lobbeck (11.1\%), Eucalyptus spp. }(4.8 \%) \text {, Rhus vulgaris }(1.6 \%) \text {, Schinus molle }(3.2 \%)\end{array}$ \\
\hline 5 & Fence & $\begin{array}{l}\text { Acacia tortilis (50.8\%), Acacia albida (1.6\%), Acacia negrii (11.1\%), Acacia seyal (3.2\%), Balanites aegyptiaca } \\
(12.7 \%) \text {, Albizia lobbeck (15.9\%), Eucalyptus spp. (1.6\%), Zizphus spina-christi }(4.8 \%)\end{array}$ \\
\hline 6 & Charcoal & $\begin{array}{l}\text { Acacia tortilis (7.9\%), Acacia negrii (4.8\%), Acacia seyal (1.6\%), Balanites aegyptiaca (12.7\%), Albizia lobbeck } \\
(1.6 \%)\end{array}$ \\
\hline 7 & $\begin{array}{l}\text { Construction (mostly } \\
\text { house) }\end{array}$ & $\begin{array}{l}\text { Acacia tortilis }(7.9 \%) \text {, Acacia negrii }(4.8 \%) \text {, Acacia seyal }(1.6 \%) \text {, Balanites aegyptiaca }(12.7 \%) \text {, Albizia lobbek } \\
(1.6 \%) \text {, Olea africana }(1.6 \%) \text {, Croton macrostachyus }(4.8 \%) \text {, Eucalyptus spp. }(12.7 \%) \text {, Cordia africana }(11.1 \%) \text {, } \\
\text { Zizphus spina-christi }(3.2 \%), \text { Rhus vulgaris }(1.6 \%) \text {, Acokanthera schimpheri }(1.6 \%) \text {, Qacacula }(4.8 \%) \text {, Milica } \\
(1.6 \%), \text { Manci }(1.6 \%)\end{array}$ \\
\hline 8 & Fertility improvement & Acacia tortilis $(9.5 \%)$, Balanites aegyptiaca $(4.8 \%)$, Albizia lobbeck $(1.6 \%)$ \\
\hline 9 & Farm Implement & $\begin{array}{l}\text { Acacia tortilis }(7.9 \%) \text {, Acacia negrii }(1.6 \%) \text {, Acacia seyal }(6.3 \%) \text {, Balanites aegyptiaca }(9.5 \%) \text {, Albizia lobbeck } \\
(7.9 \%) \text {, Olea africana }(3.2 \%) \text {, Croton macrostachyus }(4.8 \%) \text {, Cordia africana }(1.6 \%) \text {, Rhus vulgaris }(1.6 \%) \text {, Ilex } \\
\text { mitis }(1.6 \%)\end{array}$ \\
\hline 10 & House utensils & Croton macrostachyus $(3.2 \%)$ \\
\hline 11 & $\begin{array}{l}\text { Smoking (good smell for } \\
\text { house and equipment's) }\end{array}$ & Olea africana $(11.1 \%)$ \\
\hline
\end{tabular}

\subsubsection{Other Natural Resources Constraints}

Table 27. Major Agroforestry constraints in the Warja watershed.

\begin{tabular}{|c|c|c|c|}
\hline No. & $\mathrm{N}$ - agroforestry constant & Percentage (\%) & Rank \\
\hline 1 & Lack of access to inputs (improved seed/seedlings) & 57.1 & 1 \\
\hline 2 & Un availability of inputs (seed and /or seedling) on time & 6.3 & 2 \\
\hline 3 & Poor access to extension services & 4.8 & 3 \\
\hline 4 & Climatic problem/drought & 4.8 & 4 \\
\hline
\end{tabular}

Table 28. Major fruit production constraints in the Warja watershed.

\begin{tabular}{llll}
\hline No. & Constraints list & Percentage (\%) \\
\hline 1 & Climatic problem/drought & 49.2 & \\
2 & Lack of access to inputs (improved seed/seedlings, fertilizer) & 12.7 & 2.8 \\
3 & Poor access to extension services & 3.2 & 3.2 \\
4 & Un availability of inputs on time & 3 & 4 \\
\hline
\end{tabular}

Table 29. Water harvesting constraints in the Warja watershed.

\begin{tabular}{llll}
\hline No. & irrigation water harvesting contracts & Percentage (\%) \\
\hline 1 & Lack of improved water harvesting technologies & 38.1 & \\
2 & Climatic problem/shortage of rain/ & 22.2 & 1 \\
3 & Poor access to extension services on water harvesting & 2 & 12.7 \\
4 & Lack of access to credit services & 3 & 1.6 \\
\hline
\end{tabular}

\section{Conclusion and Recommendations}

\subsection{Conclusion}

Warja watershed encompasses remarkable natural capital with potential to support households residing in the area. However due to miss use of the resources on the site and less attention given for the area's resources management; surrounding societies are not utilizing the existing resources potential of the area. The cause and impact of land degradation in Warja watershed had been explored using different methods explained in the study. Natural resources degradation such as Land, and or/ soil fertility, reduction and recent changes in the areas' weather condition in line of climate change (rain fall in amount and duration, unusual length of dry season) prevailing in current years are few of the many factors that are contributing to the crop productivity reductions in the area. It was observed that in addition to the nature of the topography of the land anthropogenic factors were a great contribution for the resources depletion that affecting the societies in the area and their livelihoods. Factors that affect these natural resources depletion by hampering the production and productivities of the local community in the areas were the scarcity of land for farming family, soil infertility, and fluctuation of weather condition. These situations are happening at the expense of species diversity and bringing a reduction in food provision for 
poor rural households in addition to others resources depletion in the area. It can be concluded that planned watershed managements as interventions for Warja watershed improvements are impressive for the success of any development works carried out for the surrounding communities.

\subsection{Recommendations}

Based on the findings of this study, the following recommendations are suggested:

Attention should be given to make Warja watershed more productive for local people by improving their awareness on integrating crops, livestock and natural resource management technologies for effective soil and water conservation measures should be enhanced.

Participatory implementation of degraded land rehabilitation in the watershed particularly construction of integrated physical and biological soil and water conservation measures should have to be encouraged.

Provisions of Warja watershed should be included in the programs of conservation agency and others concerned bodies to enhance the livelihoods of rural poor and conservation of natural resources on a sustainable basis.

Provisions of improved breeds of livestock's and the modern beehives by organizing young and land less through integrated improved beekeeping practices with multi propose trees as means of income generating should be implemented.

Further study is needed to identify adoptable conservation technologies like adaptable multipurpose tree/species plant varieties of ecological and locals' needs.

\section{References}

[1] Abbadi, G. R. (2016). Evidences of Spatiotemporal Climate Change and its Mitigation in Ethiopia. Hydrol Current Res, 7, p. 220.

[2] Abbaspour, K. C., Rouholahnejad, E., Vaghefi S. R. I. N. I. V. A. S. A. N. B., Srinivasan R., Yang H. \& Kløve B. (2015). A continental-scale hydrology and water quality model for Europe: Calibration and uncertainty of a high-resolution largescale SWAT model. Journal of Hydrology, 524, pp. 733-752.

[3] Admassie, A., Adenew, B. \& Tadege, A., 2008. Perceptions of stakeholders on climate change and adaptation strategies in Ethiopia. International Food Policy Research Institute.

[4] Admassu, Z., Gizaw, A., Alemu, G., Mekonnen, K., Gebremikael, M. T., Amede, T. \& German, L. (2008). Watershed-based soil and water conservation experiences in Ethiopian highlands. In Working with communities on integrated natural resources management (pp. 27-39). Ethiopian Institute of Agricultural Research (EIAR).

[5] Allan, F., Glenn C., \& Shasta C. (2010). Primary Plant Nutrients: Nitrogen, Phosphorus, and Potassium.

[6] Anantha, K. H., Suhas P. W., \& Sreedevi T. K. (2009). Baseline Socio-economic Characterization of Watersheds; International Crops Research Institute for the Semi-Arid Tropics (ICRISAT) Patancheru 502 324, Andhra Pradesh,
India.

[7] Betteridge, K., Mackay, A. D., Shepherd T. G., Barker D. J., Budding P. J., Devantier B. P., \& Costall D. A. (1999). Effect of cattle and sheep treading on surface configuration of a sedimentary hill soil. Soil Research, 37 (4), pp. 743-760.

[8] Blackburn, J. \& Holland J. (eds.). (1998). Who Changes? Institutionalising Participation in development. London: Intermediate Technology Publication Ltd.

[9] Blaikie, P. (1987). Explanation and Policy in Land Degradation and Rehabilitation for Developing Countries. Land Degradation and Rehabilitation, 1, 23-27.

[10] Blaikie, P. (2001). Is Policy Reform Pure Nostaligia? A Himalayan Illustration: Barkeley Workshop on Environmental Politics. California, Berkeley: Institute of International Studies, University of California.

[11] Botero, L. S. (1986). Incentives for Community Involvement in Upland Conservation. Strategies, approaches and system in integrated watershed management. Rome: FAO Conservation Guide 14.

[12] Brooks, N. K., Folliot P. F., \& Thames J. L. (1991). Watershed Management: A Global Perspective, Hydrology and the Management of Watersheds. Ames, Iowa: Iowa State University Press pp1-7.

[13] Datta, S. K. \& K. J. Virgo. (1998). Towards Sustainable Watershed Development through People's Participation: Lesson from the Lesser Himalaya, Utter Pradesh, India. Mountain Research and Development 18 (1), 213-233.

[14] Díaz, S., Demissew, S., Carabias, J., Joly, C., Lonsdale, M., Ash, N., Larigauderie, A., Adhikari, J. R., Arico, S., Báldi, A. \& Bartuska, A. (2015). The IPBES Conceptual Frameworkconnecting nature and people. Current Opinion in Environmental Sustainability, 14, pp. 1-16.

[15] Ethiopia. Office of the Population and Housing Census Commission, 2008. Summary and statistical report of the 2007 population and housing census: population size by age and sex. Federal Democratic Republic of Ethiopia, Population Census Commission.

[16] Gebregziabher, G., Abera, D. A., Gebresamuel, G., Giordano, M. \& Langan, S. (2016). An assessment of integrated watershed management in Ethiopia (Vol. 170). International Water Management Institute (IWMI).

[17] Gebrehiwot, T. and Van der Veen, A. (2013). Farm level adaptation to climate change: the case of farmer's in the Ethiopian Highlands. Environmental management, 52 (1), pp. 29-44.

[18] Haregeweyn, N., Berhe, A., Tsunekawa, A., Tsubo, M. \& Meshesha, D. T. (2012). Integrated watershed management as an effective approach to curb land degradation: a case study of the enabered watershed in Northern Ethiopia. Environmental management, 50 (6), pp. 1219-1233.

[19] Horneck, D. A., Sullivan, D. M., Owen, J. S. \& Hart, J. M. (2011). Soil test interpretation guide.

[20] Hunt, N. \& Gilkes, R. (1992). Farm Monitoring Handbook. The University of Western Australia: Nedlands, WA. McKenzie N, Coughlan K and Cresswell H (2002) Soil Physical Measurement and Interpretation for Land Evaluation. CSIRO Publishing: Collingwood, Victoria. 
[21] McKenzie, N., Coughlan K. \& Cresswell H. (2002). Soil physical measurement and interpretation for land evaluation (Vol. 5). Csiro Publishing.

[22] Mesku, D., Zeleke, A., Yasin, A., \& Wole, K. (2008). FRG Project Completed Repass, EIAR, OARI and JAICA Cooperation, Adami Tulu Agricultural Research Center.

[23] Mutekanga, F. P. (2012). Participatory policy development for integrated watershed management in Uganda's highlands.

[24] Pielou, E. C. (1969). An Introduction to Mathematical Ecology. Wiley, New York.
[25] Spargo, J., Allen, T. \& Kariuki, S. (2013). Interpreting your soil test results. The College of Natural Sciences, Soil and Plant Tissue Testing Laboratory, USDA, Amherst. MA.: $\mathrm{http}: / /$ soiltest.umass.edu/.

[26] Zenebe A. (2005). The Impact of Land tenure Systems on Soil and Water Conservation Practices in Berissa Watershed, Ethiopia. MSc Thesis, Wageningen University and Research center, The Netherlands. Pp 107. 